\title{
Planning experiment for laboratory tests on rock abrasivity
}

\begin{abstract}
The physical and mechanical properties of rocks (i.e., compressive strength, tensile strength, workability, or compactness) are often taken into account during the selection of a mining method and type of mining machine as well as the mining tools themselves. However, one of the main reasons for the abrasive wear of mining picks is the abrasiveness of rocks, which is seldom taken into consideration because there is lack of unambiguous and proven methods for its determination.

The article presents the research plan and methodology, the stand for testing the abrasivity of rocks, the course of conducting preliminary tests as well as the statistical treatment of the results using the Statistica program, and determining the final values of the input variables in the basic research. The method has been developed taking into account rock abrasivity when selecting and forecasting the wear of mining tools.
\end{abstract}

Key words: rock abrasivity, design of experiment, laboratory test method, statistical analysis, mining tools, abrasive wear

\section{INTRODUCTION}

Knowledge of the physical and mechanical properties of rocks is of great importance in the design and implementation of all engineering projects in mining and underground construction. It is necessary to evaluate the stability of the rock mass in the vicinity of excavations and provide conditions for the safe use of the excavations and safe work [1]. Physical-mechanical parameters should also be considered as the basis for choosing the method of mechanical mining. This expertise allows us to evaluate the usefulness of rocks as well as assess the behavior of rocks during the mining process [2].

An element that is in direct contact with the mined rock during extraction work is the cutting pick. As a result of the mining process, the tools are subjected to excessive wear, most often by abrasion. Their wear can have very serious consequences, among which are changes in the geometrical shape of the pick, losses in its weight, a loss of its cutting capacity, frequent pick replacement, shortening the working time of the min- ing machine, reduced efficiency, and increased energy consumption and mining costs [3, 4].

When selecting mining tools, various aspects are taken into account among other geological properties as well as the physical and mechanical properties of the rocks, where the most commonly considered parameters are uniaxial compression strength, uniaxial tensile strength, compactness, and workability. It is also necessary to choose the right material and construction of the picks so that their durability is as great as possible with the parameters given as well as the cutting process conditions $[3,4]$.

When selecting mining tools, the abrasivity of rocks is very rarely taken into account. This is due to the lack of a clearly defined method of its determination. The only commonly known test method for identifying a rock's abrasivity is the Cerchar Abrasivity Index (CAI) [5, 6]. This test is used by the Sandvik company; however, the test results are a company secret. Often, the rock abrasivity testing methods are confused with rock abrasiveness testing methods, as described in publication [3]. 
In connection with all of the above, a new rock abrasivity test method has been developed (which is described in this article).

\section{LABORATORY TEST STAND}

The abrasivity of rocks is determined using abrasivity index $W_{z}$. The formula of its determination is based on the evaluation of the durability of the cutting picks. Under industrial conditions, the durability of cutting picks is usually defined as the ratio of the number of replaced picks to the weight or volume of the extracted material. Most frequently, it is the number of worn picks necessary to obtain $1000 \mathrm{Mg}$ or $1000 \mathrm{~m}^{3}$ of extracted material. However, under laboratory conditions, the wear rate (durability) of picks is most effectively determined on the basis of the loss of their weight in relation to the volume of the rock specimen extracted [4]. On this basis, the abrasivity index is defined as the ratio of the loss weight of the model steel pin to the weight loss of the tested rock sample (1).

$$
W_{z}=\frac{M_{p a}}{M_{p i}}
$$

where:

$W_{z}-$ abrasivity index [-],

$M_{p i}$ - weight loss of the rock sample [g],

$M_{p a}$ - weight loss of the steel pin [g],

$$
M_{p a}=M_{p a b}-M_{p a a}
$$

where:

$$
M_{p a b} \text { - steel pin weight before test [g], }
$$

$M_{p a a}$ - steel pin weight after test [g],

$$
M_{p i}=M_{p i b}-M_{p i a}
$$

where:

$M_{\text {pib }}$ - rock sample weight before test [g],

$M_{\text {pia }}$ - rock sample weight after test [g].

The method of determining the abrasivity index has forced the design and construction of a laboratory test stand (Fig. 1). The test stand has a drive unit that carries out rotational movement of the steel pin at a constant speed. On the shaft of the gearmotor, there is a holder in which a steel pin is fixed. Together with the rock sample, they form an abrasive pair (Fig. 2).
The steel pin is constantly pressed against the face of the rock sample by means of a gravitational holdingdown system with the weights. A detailed description of the test stand has been presented in publication [7].

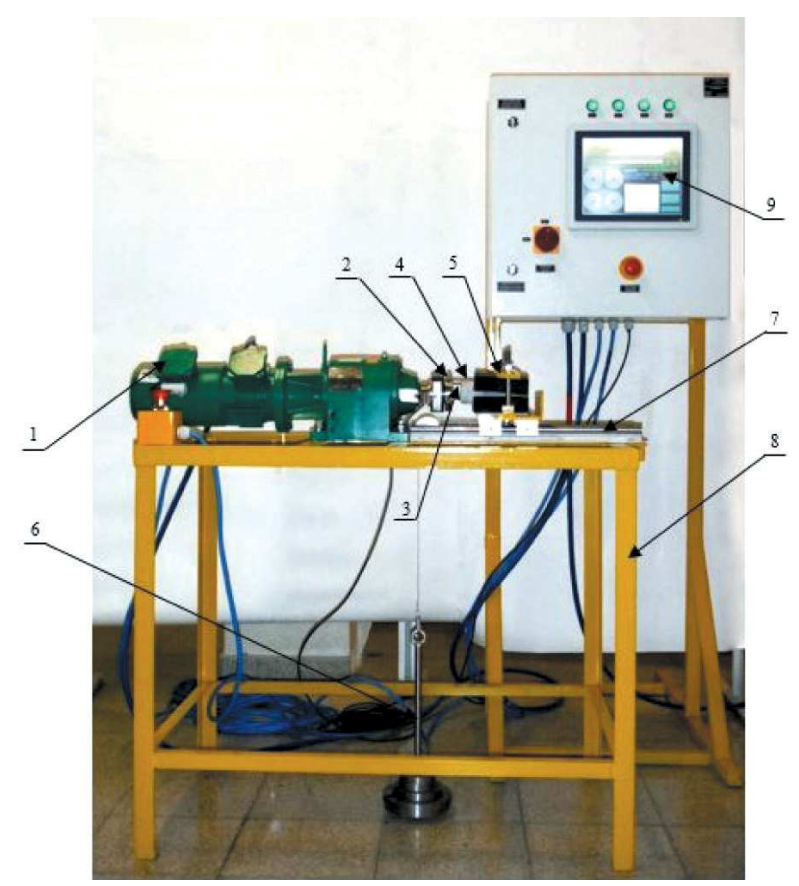

Fig. 1. Test stand for determining rock abrasivity: 1 - drive unit, 2 - steel pin, 3 - holder of steel pin, 4-rock sample, 5-holder of rock sample, 6-gravitational holding-down system, 7 - sliding system, 8 - supporting frame, 9 - control panel

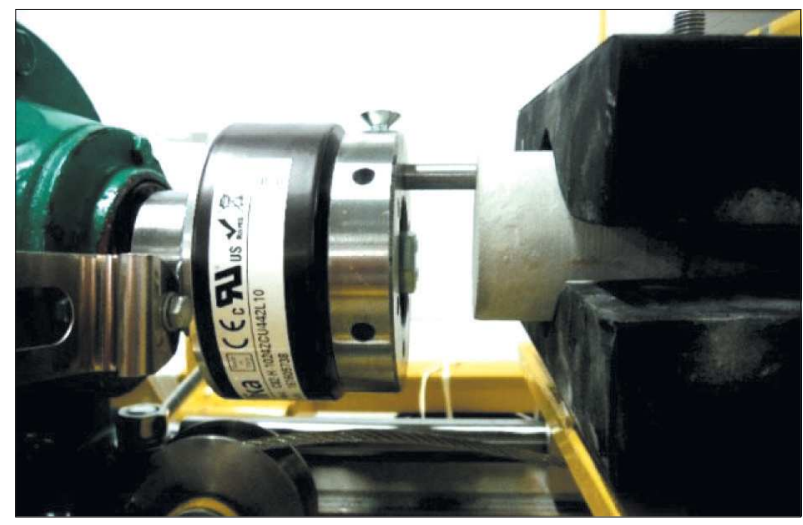

Fig. 2. View of abrasive pair

\section{PURPOSE AND CHARACTERISTIC OF RESEARCH OBJECT}

The first important step in the research is to raise a research problem that requires a solution through experimentation and a description of the research 
object. The goal of each type of experimental research is to obtain information on the relationship between the input (set parameters) and output variables (wanted parameters). This type of relationship is usually represented as an approximating function of a research object $[8,9]$.

Characteristics of the research object lie in determining a set of input and output variables. This stage of research is of key importance, as the errors connected with the inaccurate recognition of the research object may result in obtaining a lack-of-fit model as well as a loss of money and time. It is therefore important to become familiar with the topic, which is described in article [3].

In the preliminary research described in this article, the main goal was to determine the form of the functions for three different rock samples and then calculate the values of the input variables that stay unchanged in the basic research. Abrasivity index $W_{z}$ is an output variable, whereas the input variables are as follows:

- feed force of the steel pin to the rock sample $P_{d}$ $[\mathrm{N}]$,

- rotational speed of the steel pin $n$ [rpm],

- time of single test $t$ [min].

The subject of the research are two types of natural rocks (sandstone and porphyry) as well as concrete (shown in Fig. 3).

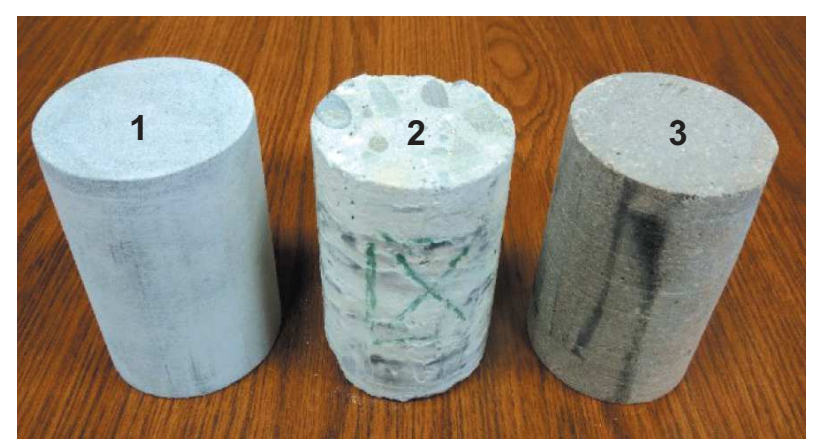

Fig. 3. View of prepared samples for tests: 1 - sandstone, 2 - concrete, 3 - porphyry

The selection of such a set of samples was conditioned by different physico-mechanical properties and diversified mineralogical and chemical composition. Particular attention is paid to the value of uniaxial compression strength. Sandstone is a rock with high strength and has good abrasive properties due to its high silica $\left(\mathrm{SiO}_{2}\right)$ content. Porphyry is a rock with medium strength and also has good abrasive properties due to its silica $\left(\mathrm{SiO}_{2}\right)$ content. On the other hand, C16/20 concrete was selected for artificial samples to obtain samples with low compressive strength and additionally basalt aggregate was added in order to check whether the inclusions would chip or not.

Table 1

Uniaxial compressive strength and percentage content of silica $\left(\mathrm{SiO}_{2}\right)$ in tested samples

\begin{tabular}{|l|c|c|}
\hline \multicolumn{1}{|c|}{ Sample } & $\begin{array}{c}\text { Uniaxial } \\
\text { compressive } \\
\text { strength } \\
\boldsymbol{R}_{\boldsymbol{c}}[\mathbf{M P a}]\end{array}$ & $\begin{array}{c}\text { Content } \\
\text { of silica } \mathrm{SiO}_{2} \\
{[\%]}\end{array}$ \\
\hline Sandstone & $100-110$ & 27.7 \\
\hline Porphyry & $32-53$ & 21.9 \\
\hline Concrete & $20-25$ & 15.2 \\
\hline
\end{tabular}

\section{SELECTION OF DESIGN OF EXPERIMENT}

In order to reduce the workload and time consumption, the scope of the research is most often narrowed by eliminating input variables or reducing the number of input variables [8]. The best solution is to apply the proper design of the experiment. One of its greatest advantages is the ability to obtain measurable effects by reducing the work needed to conduct an experiment; it also reduces time consumption. However, the choice of the design of the experiment depends on the purpose and specificity of the type of research. Using the theory of the experiment, one should choose a design of an experiment that meets the basic criteria of informativity, realizability, and efficiency [8-10].

As mentioned before, there are three input variables and one output variable in the case of the described research. Assuming nonlinear functional relationships between the input and output variables, a test is carried out for five intermediate values. It is assumed that, for the first variable (which is the $P_{d}$ feed force), the variation range is $150-350 \mathrm{~N}$. For the second variable, the rotational speed of steel pin $n$ varies between $20-55 \mathrm{rpm}$, and for the third (time of single test $t$ ), the range is $4-12 \mathrm{~min}$. 
Due to the high efficiency, the ability to describe nonlinear models of the research object and at the same time the compositionality (that is, the ability to verify the linear model), Hartley's test ( $P S / D S-P: H a_{3}$ ) based on a hypersphere has been selected. It is a test that belongs to the static determined and polyselective tests for three input variables in which five different values are used for each input variable [9].

The basic principle of creating polyselective tests is the deliberate selection of a combination of input variables (in the previously assumed range) in such a way that it is possible to obtain the required scientific information with a limited workload; that is, with a relatively small number of measurements $[9,10]$. The Statistica program is very helpful at this stage of the research. It enables the generation of various types of design of experiments thanks to the Design \& Analysis of Experiments Startup Panel [11].

The choice of a polyselective test significantly reduces the number of necessary single tests as related to the full factorial design. As be seen in Table 2, the combinations of values of input variables from Numbers 11 through 14 show the same combination of input variables. Repetition of the experiment for these combinations is necessary to determine the errors of the assumed approximating function of a research object.

Table 2

Combinations of values of input variables applied during preliminary research in Hartley's test

\begin{tabular}{|c|c|c|c|}
\hline $\begin{array}{c}\text { Hartley's test } \\
\text { treatments }\end{array}$ & $\begin{array}{c}\text { Feed } \\
\text { speed } \\
\boldsymbol{P}_{\boldsymbol{d}}\end{array}$ & $\begin{array}{c}\text { Rotational } \\
\text { speed } \\
\boldsymbol{n}\end{array}$ & $\begin{array}{c}\text { Single } \\
\text { test time } \\
\boldsymbol{t}\end{array}$ \\
\hline 1 & 192 & 27 & 10 \\
\hline 2 & 308 & 27 & 6 \\
\hline 3 & 192 & 48 & 6 \\
\hline 4 & 308 & 48 & 10 \\
\hline 5 & 150 & 37 & 8 \\
\hline 6 & 350 & 37 & 8 \\
\hline 7 & 250 & 20 & 8 \\
\hline 8 & 250 & 55 & 8 \\
\hline 9 & 250 & 37 & 4 \\
\hline 10 & 250 & 37 & 12 \\
\hline 11 & 250 & 37 & 8 \\
\hline 12 & 250 & 37 & 8 \\
\hline 13 & 250 & 37 & 8 \\
\hline 14 & 250 & 37 & 8 \\
\hline & & & \\
\hline
\end{tabular}

Unfortunately, after doing the tests for the determined design of the experiment and carrying out the statistical analysis of the tests results, it is found that the designated functions of the research object for each tested sample are a lack-of-fit as related to the measurement results. Additional tests are carried out for several other designs of the experiments; however, each time too few measurements are obtained, thus attaining an inaccurate function describing the research object. In connection with all of the above, the need arises to use a full factorial design.

\section{EXECUTION OF RESEARCH PLAN}

The choice of a full factorial design is associated with a large amount of work and is excessively timeconsuming. Due to the cognitive character of the research, the range of variability of the input variables is expanded for the full factorial design as related to the previously mentioned designs of the experiments. It has been decided to obtain a greater amount of data in order to determine a more precise approximating function of a research object. The ranges of variation and the values tested for the full factorial design are presented in Table 3. The input variables' values are chosen symmetrically for each range of the variations. Such a selection is necessary to accurately reflect the character of the variability of the input variables for the research result $[9,12]$.

Table 3

\section{Ranges of variation and selected values of input variables}

\begin{tabular}{|l|c|c|c|}
\hline \multicolumn{1}{|c|}{$\begin{array}{c}\text { Input } \\
\text { variables }\end{array}$} & $\begin{array}{c}\text { Feed force } \\
\boldsymbol{P}_{\boldsymbol{d}}[\mathbf{N}]\end{array}$ & $\begin{array}{c}\text { Rotational } \\
\text { speed } \boldsymbol{n}[\mathbf{r p m}]\end{array}$ & $\begin{array}{c}\text { Single test } \\
\text { time } \boldsymbol{t}[\mathbf{m i n}]\end{array}$ \\
\hline $\begin{array}{l}\text { Ranges } \\
\text { of variation }\end{array}$ & $100-400$ & $10-65$ & $2-15$ \\
\hline $\begin{array}{l}\text { Selected } \\
\text { values }\end{array}$ & $\begin{array}{c}100,200, \\
300,400\end{array}$ & $10,30,50,65$ & $2,5,10,15$ \\
\hline
\end{tabular}

The combinations of the values of the input variables accepted for the individual tests are determined by the full factorial design. Having three input variables with four test values each means that 64 single tests $(4 \times 4 \times 4)$ have to be carried out for each sample. For the three rocks, the total number of single tests is 192. Due to the large amount of data, individual treatments of the full factorial design are not included in this article. 
The tests are carried out on a laboratory test stand for determining rock abrasivity (described in the second chapter) according to the following research plan:

- preparation of rock samples and measurement of their weight,

- preparation of steel pins for testing and measuring their weight,

- fixing the steel pin and rock sample in the holders on the test stand,

- setting the test time and rotational speed of the steel pin on the control panel,

- setting the feed force of the rock sample to the steel pin by means of a gravitational holding-down system with weights,

- carrying out the test,

- releasing the feed force,

- dismantling the steel pin and measuring its weight,

- dismantling the rock sample and measuring its weight,

- calculation of the weight loss of the steel pin and rock sample,

- determination of abrasivity index $W_{z}$.

In addition to the abrasivity index $W_{z}$ values for each combination of input values, the carried-out tests enable us to obtain many other valuable conclusions, including the following:

- a test time of 2 minutes is too short, while a feed force of a steel pin to a rock sample of $100 \mathrm{~N}$ and a rotational speed of $10 \mathrm{rpm}$ are both too small to obtain a measurable wear of a steel pin with the necessary accuracy of 0.01 grams,

- a rotational speed of a steel pin at $65 \mathrm{rpm}$ and a feed force of $400 \mathrm{~N}$ (independent of the time of a single test) cause it to heat up, consequently leading up to the high-temperature sliding wear of a steel pin and even its melting.

Based on the above observations, the treatments with these input values and, thus, the values of abra- sivity index $W_{z}$, are not taken into account in the analysis of the results.

\section{ANALYSIS OF RESEARCH RESULTS AND SELECTION FUNCTIONS OF RESEARCH OBJECT}

Having determined the abrasivity indices for all treatments of full factorial design, an analysis of the research results is performed to determine the functions of the research object for each sample.

Predetermined significance level $p$ is 0.05 in all simulations; this is a value usually accepted in technical experimental studies [8-12].

The first step in the analysis of the results is to check if the variance is homogenous. This is a prerequisite condition. The lack of homogeneity of the variance enables a search for the functions of the research object. The homogeneity of variance is carried out with the Brown-Forsythe test with the Statistica program using the Basic Statistics and Tables module (One-way ANOVA). If the test gives non-statistically significant results $(p=0.05)$, then the null hypothesis should be accepted [8]. As can be seen in Figure 4, significance level $\mathrm{p}$ is higher than 0.05 for all three tested rocks; hence, the variance is homogenous.

Before determining the functions of the research object, it is also checked whether the influence of the input variables on the output variable is significant or not. The verification is carried out with the F-test (Fisher's test) using the Basic Statistics and Tables module (One-way ANOVA, Analysis of Variance). The obtained values of significance level $\mathrm{p}$ lower than 0.05 indicate a noteworthy influence of the input variables on the output variable.

The analysis of variance (Fig. 5) carried out using the F-test showed a significant effect of the feed force, rotational speed, and test time on the abrasivity index value for all three tested rock samples.

\begin{tabular}{|c|c|c|c|c|c|c|c|c|}
\hline \multirow[b]{2}{*}{ Variable } & \multicolumn{8}{|c|}{$\begin{array}{l}\text { Brown-Forsythe test (Full factorial design) } \\
\text { Marked effects are significant at } p<.05000\end{array}$} \\
\hline & $\begin{array}{c}\text { SS } \\
\text { Effect }\end{array}$ & $\begin{array}{c}\text { df } \\
\text { Effect }\end{array}$ & $\begin{array}{c}\text { MS } \\
\text { Effect }\end{array}$ & $\begin{array}{l}\text { SS } \\
\text { Error }\end{array}$ & $\begin{array}{l}\text { df } \\
\text { Error }\end{array}$ & $\begin{array}{l}\text { MS } \\
\text { Error }\end{array}$ & $F$ & $p$ \\
\hline Wz (sand) & 1.120500 & 3 & 0.560250 & 3.580000 & 60 & 0.210588 & 2.660405 & 0.098806 \\
\hline Wz (con) & 0.114500 & 3 & 0.057250 & 1.097500 & 60 & 0.064559 & 0.886788 & 0.430196 \\
\hline Wz (por) & 0.009656 & 3 & 0.004828 & 0.033594 & 60 & 0.001976 & 2.443256 & 0.116766 \\
\hline
\end{tabular}

Fig. 4. Results of Brown-Forsythe test for all three tested rocks 


\begin{tabular}{|l|r|r|r|r|r|r|r|r|}
\hline \multirow{7}{*}{$\begin{array}{l}\text { Variable } \\
\text { Varked effects are significant at } p<.05000\end{array}$} \\
\cline { 2 - 10 } & $\begin{array}{c}\text { SS } \\
\text { Effect }\end{array}$ & $\begin{array}{c}\text { df } \\
\text { Effect }\end{array}$ & $\begin{array}{c}\text { MS } \\
\text { Effect }\end{array}$ & $\begin{array}{c}\text { SS } \\
\text { Error }\end{array}$ & $\begin{array}{c}\text { df } \\
\text { Error }\end{array}$ & $\begin{array}{c}\text { MS } \\
\text { Error }\end{array}$ & F & p \\
\hline Wz (sand) & 29.06889 & 3 & 9.689629 & 77.74373 & 60 & 1.295729 & 7.478131 & 0.000247 \\
\hline Wz (con) & 7.96197 & 3 & 2.653991 & 30.38804 & 60 & 0.506467 & 5.240201 & 0.002804 \\
\hline Wz (por) & 8.84422 & 3 & 2.948073 & 28.13938 & 60 & 0.468990 & 6.286009 & 0.000882 \\
\hline
\end{tabular}

Fig. 5. Results of F-test for all three tested rocks

When analyzing the results, the value of $P_{d}$ is divided by 10 to minimize numeric errors. Next, the form of the function describing the empirical dependence (4) for each of the examined rocks is determined. A preliminary comparison of the degree of adequacy of the various forms of the approximation functions describing dependence (4) resulted in the selection of the form of the function as a second-degree polynomial with double interactions (5).

$$
\begin{aligned}
& W_{z}=f\left(P_{d}, n, t\right) \\
& z=b_{0}+b_{1} x_{1}+b_{2} x_{2}+b_{3} x_{3}+b_{11} x_{1}^{2}+b_{22} x_{2}^{2}+ \\
& \quad+b_{33} x_{3}^{2}+b_{12} x_{1} x_{2}+b_{13} x_{1} x_{3}+b_{23} x_{2} x_{3}
\end{aligned}
$$

The number of unknowns $b_{j}$ of the proposed approximation polynomial is 10 and is smaller than the number of treatments of the full factorial design, which fulfills the necessary condition due to the criterion of informativity [7]. The $b_{j}$ constants are calculated with the quasi-Newton estimation method using the Statistica program.

On the basis of an analysis of the coefficients of significance $b_{j}$ carried out using the Student t-test, the rejected coefficients are considered non-significant (with a significance level of 0.05). The Advanced Linear/Nonlinear Models module (Nonlinear Estimation, User-Specified Regression) is used. The significance coefficients are marked in red (Fig. 6). Then, it is required to remove the components with non-significant coefficients from the polynomial and regenerate the new coefficients of the equation so that all of them are marked in red (all considered significant).

An example of the results for sandstone is presented in Figure 6. In the same way, the analysis of significance is also carried out for porphyry and concrete. The approximating functions for the three tested rocks are as follows:

- sandstone:

$$
\begin{aligned}
W_{z_{1}} & =-3.67+0.66 \cdot t+ \\
& +0.2 \cdot P_{d}-0.03 \cdot t^{2}-3 \cdot 10^{-3} \cdot P_{d}^{2}
\end{aligned}
$$

- concrete:

$$
\begin{aligned}
W_{z_{2}} & =-2.45+0.3 \cdot t+ \\
& +0.17 \cdot P_{d}-0.014 \cdot t^{2}-3.3 \cdot 10^{-3} \cdot P_{d}^{2}
\end{aligned}
$$

- porphyry:

$$
\begin{aligned}
W_{z_{3}} & =-6.8 \cdot 10^{-3} \cdot t^{2}-2.6 \cdot 10^{-4} \cdot n^{2}- \\
& +7.2 \cdot 10^{-4} \cdot P_{d}^{2}+1.6 \cdot 10^{-3} \cdot t \cdot n+ \\
& +4.3 \cdot 10^{-3} \cdot t \cdot P_{d}+8.7 \cdot 10^{-4} \cdot n \cdot P_{d}
\end{aligned}
$$

where:

$$
\begin{aligned}
W_{z}- & \text { abrasivity index }[-], \\
t- & \text { time of single test [min], } \\
n- & \text { rotational speed of the steel pin }[\mathrm{rpm}], \\
P_{d}- & \text { feed force of the steel pin to the rock } \\
& \text { sample [N]. }
\end{aligned}
$$

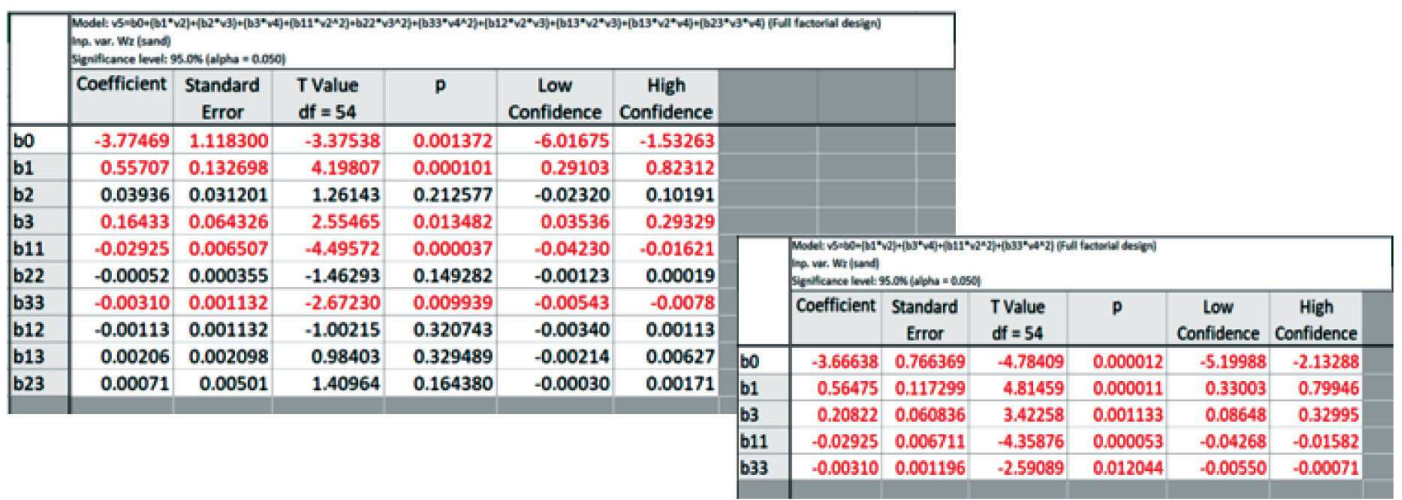

Fig. 6. Elimination of non-significant coefficients in Statistica program on example of sandstone test results 
After removing the non-significant coefficients in each designated function, the adequacy of the research object function for the test results is checked. The adequacy is verified with the use of the $\chi^{2}$ (chi-square) test. The achieved significance level $p$ is 0.120 (average value); it is greater than 0.05 , which proves that the obtained functions are adequate in relation to the test results. In addition, correlation ratio $R$ for the designated functions are also checked. For sandstone, this is $R=0.92$; for porphyry $-R=0.90$; and for concrete $-R=0.81$ (Fig. 7).

\begin{tabular}{|l|c|c|c|}
\hline Variable & R & R Square & $\begin{array}{c}\text { Adjusted } R \\
\text { Square }\end{array}$ \\
\hline Wz (sand) & 0.918444 & 0.843539 & 0.765309 \\
\hline Wz (con) & 0.907918 & 0.824316 & 0.736473 \\
\hline Wz (por) & 0.808076 & 0.652987 & 0.479480 \\
\hline
\end{tabular}

Fig. 7. Correlation ratios for designated functions

Then, from Equations (6), (7), and (8), simultaneous equations (9) are arranged and solved using the MATLAB program in order to obtain the final values of the input variables $P_{d}, n$, and $t$. Each equation is compared to the maximum value of abrasivity index $W_{z}$, which is obtained during the tests in order to determine the minimum values of the input variables at which the steel pin has the greatest wear.

$$
\left\{\begin{array}{l}
-3.67+0.66 \cdot t+0.2 \cdot P_{d}-0.03 \cdot t^{2}-3 \cdot 10^{-3} \cdot P_{d}^{2}=3.0 \\
-2.45+0.3 \cdot t+0.17 \cdot P_{d}-0.014 \cdot t^{2}-3.3 \cdot 10^{-3} \cdot P_{d}^{2}=1.4 \\
-6.8 \cdot 10^{-3} \cdot t^{2}-2.6 \cdot 10^{-4} \cdot n^{2}-7.2 \cdot 10^{-4} \cdot P_{d}^{2}+1.6 \cdot 10^{-3} \cdot t \cdot n+ \\
\quad+4.3 \cdot 10^{-3} \cdot t \cdot P_{d}+8.7 \cdot 10^{-4} \cdot n \cdot P_{d}=1.7
\end{array}\right.
$$

After solving the above simultaneous equations, the following values of the input variables are obtained: test time $t=7.88 \mathrm{~min}$; rotational speed $n=50.37 \mathrm{rpm}$; and feed force of the steel pin to the rock sample $P_{d}=30.48 \mathrm{~N}$.
As previously mentioned, the $P_{d}$ force value is divided by 10 to reduce numerical errors. Therefore, the next step is to carry out check tests for the three tested rocks with the following values of input variables: $t=8 \mathrm{~min}, n=50 \mathrm{rpm}$, and $P_{d}=300 \mathrm{~N}$.

Then, tests are carried out for the designated input variables for the three tested rocks. Five replicates are made for each rock to check the repeatability of the results; these results are summarized in Table 4. In addition to each of the determined equations, the calculated input variables are substituted and obtained: for sandstone:

$$
\begin{aligned}
& W_{z_{1}}=-3.67+0.66 \cdot 8+0.2 \cdot 35- \\
& \quad+0.03 \cdot 8^{2}-3 \cdot 10^{-3} \cdot 35^{2}=3.0
\end{aligned}
$$

for concrete:

$$
\begin{aligned}
& W_{z_{2}}=-2.45+0.3 \cdot 8+0.17 \cdot 35- \\
& \quad+0.014 \cdot 8^{2}-3.3 \cdot 10^{-3} \cdot 35^{2}=1.0
\end{aligned}
$$

for porphyry:

$$
\begin{aligned}
W_{z_{3}} & =-6.8 \cdot 10^{-3} \cdot 8^{2}-2.6 \cdot 10^{-4} \cdot 50^{2}- \\
& +7.2 \cdot 10^{-4} \cdot 35^{2}+1.6 \cdot 10^{-3} \cdot 8 \cdot 50 \\
& +4.3 \cdot 10^{-3} \cdot 8 \cdot 35+8.7 \cdot 10^{-4} \cdot 50 \cdot 35=1.4
\end{aligned}
$$

While analyzing the values of abrasivity index $W_{z}$ from Table 4, it can be seen that the test results are almost identical to those obtained from the equations. This means that the selected approximating functions have been well-fitted, describing the object of research thoroughly.

As previously mentioned, the steel pin melts in several single tests. A too-high temperature of the

\begin{tabular}{|c|c|c|c|c|c|c|}
\hline No. & $P_{d}[\mathrm{~N}]$ & $n$ [rpm] & $t[\mathrm{~min}]$ & $\begin{array}{c}W_{z} \\
\text { (sandstone) }\end{array}$ & $\begin{array}{c}W_{z} \\
\text { (concrete) }\end{array}$ & $\begin{array}{c}W_{z} \\
\text { (porphyry) }\end{array}$ \\
\hline 1 & \multirow{5}{*}{350} & \multirow{5}{*}{50} & \multirow{5}{*}{8} & 3.2 & 1.0 & 1.4 \\
\hline 2 & & & & 3.0 & 1.1 & 1.3 \\
\hline 3 & & & & 3.0 & 1.1 & 1.3 \\
\hline 4 & & & & 3.1 & 1.0 & 1.3 \\
\hline 5 & & & & 2.9 & 1.1 & 1.4 \\
\hline \multicolumn{4}{|c|}{ Average value from test } & 3.1 & 1.1 & 1.3 \\
\hline \multicolumn{4}{|c|}{ Value form equations } & 3.0 & 1.0 & 1.4 \\
\hline
\end{tabular}
steel pin may change the material properties of the steel and lead to thermal wear. Due to this, the temperature of the steel pin for each single test from Table 4 is checked by the thermal imaging camera for the determined values of the input variables.

Table 4

Comparison of test results for three rocks for designated input variables 
As shown in Figure 8, the maximum temperature of the steel pin fluctuates between $55-70^{\circ} \mathrm{C}$ regardless of rock sample type. Such a temperature neither makes the steel pin heat up too much nor shows a greater influence of heating wear on the abrasive wear $[13,14]$.

a)

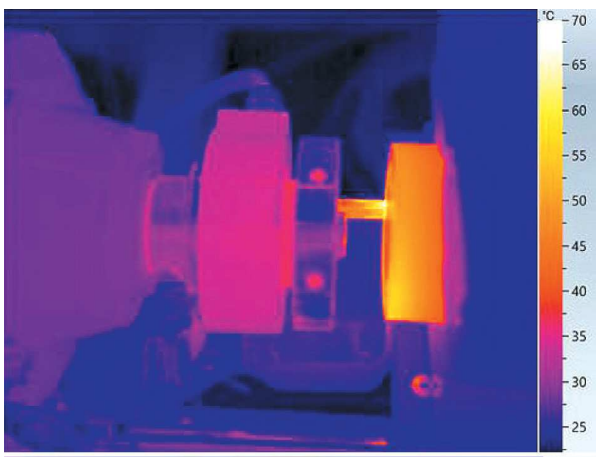

b)

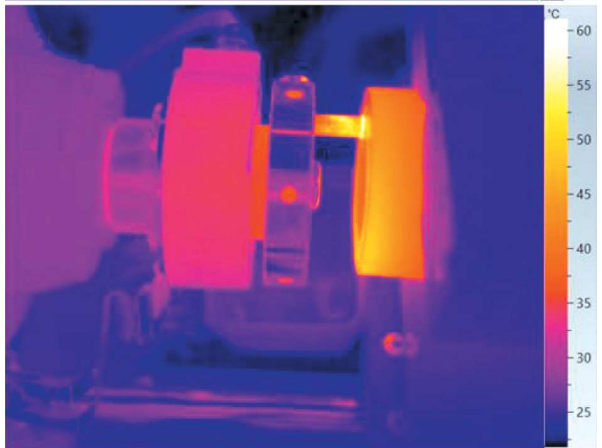

c)

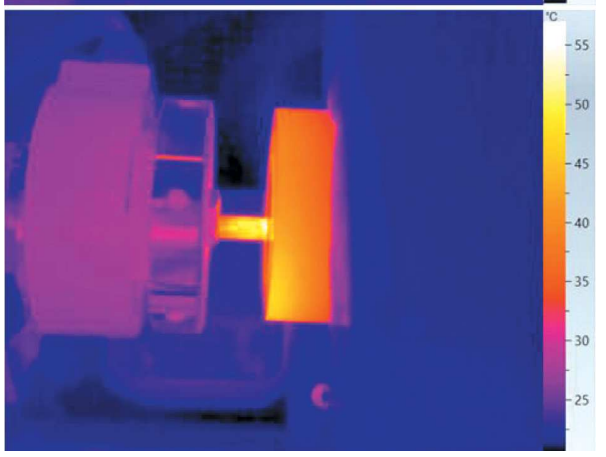

Fig. 8. Thermographic images of maximum temperature pattern during tests: a) sandstone; b) porphyry; c) concrete

\section{SUMMARY}

Carrying out preliminary research and statistical analysis of the results allowed us to verify the assumptions and make corrections in the research plan and methodology. The choice of a full factorial design allowed us to maintain a satisfactory accuracy in the determination of the approximating function of the interrelations between the input variables and the output variable. The most important goal was to determine the final values of the input variables: a feed force of the steel pin to the rock sample equal to $300 \mathrm{~N}$, a rotational speed of steel pin equal to $50 \mathrm{rpm}$, and a test time of 8 minutes.
The next step will be to carry out basic research for different types of rocks. These will include limestone, dolomite, granite, marble, metal ores, various types of sandstone, and basalt (among others).

\section{Acknowledgements}

The works have been carried out within the framework of the Dean Grant in the Faculty of Mechanical Engineering and Robotics at AGH under Agreement no. 15.11 .130 .841 .

\section{References}

[1] Piątek P.: Test punktowy, test brazylijski $i$ jest na jednoosiowe ściskanie - badania porównawcze, "Górnictwo i Geoinżynieria" 2008, 32, 1: 285-292.

[2] Hobler M.: Badania fizykomechanicznych własności skat, Państwowe Wydawnictwo Naukowe, Warszawa 1977.

[3] Krauze K., Mucha K.: Analiza metod określania ścierności skat, in: Mechanizacja, automatyzacja i robotyzacja $w$ górnictwie. Tom 1: Wybrane problemy górnictwa podziemnego. Monografia, red. K. Krauze, Lędziny - Kraków 2015: 171-180.

[4] Krauze K., Bołoz Ł., Wydro T., Mucha K.: Durability testing of tangential - rotary picks made of different materials, "Mining - Informatics, Automation and Electrical Engineering" 2017, 1: 26-34.

[5] Käsling H., Thuro K.: Determining abrasivity of rock and soil in the laboratory, Geologically Active. Proceedings of the 11th IAEG Congress, Auckland, New Zealand, 2010: 1973-1980.

[6] Nilsen B., Dahl F., Holzhauser J., Raleigh P.: Abrasivity testing for rock and soil, "Tunnels and Tunnelling International" 2006, 4: 47-49.

[7] Krauze K., Mucha K.: Laboratoryjna metoda badania ścierności skat, in: Mechanizacja, automatyzacja i robotyzacja w górnictwie. Tom 1: Wybrane problemy górnictwa podziemnego. Monografia, red. K. Krauze, Lędziny - Kraków 2016: $118-125$.

[8] Konkol J.: Wprowadzenie do praktycznego planowania eksperymentu, Wydawnictwo StatSoft Polska Sp. z o.o, Kraków 2008: 43-58.

[9] Polański Z.: Planowanie doświadczeń w technice, Państwowe Wydawnictwo Naukowe, Warszawa 1984.

[10] Górecka R.: Teoria i technika eksperymentu, Wydawnictwo Politechniki Krakowskiej, Kraków 1996.

[11] Rabiej M.: Statystyka z programem Statistica, Wydawnictwo Helion, Gliwice 2012.

[12] Strzałkowski A., Śliżyński A.: Matematyczne metody opracowania wyników pomiarów, Państwowe Wydawnictwo Naukowe, Warszawa 1973.

[13] Gierek A.: Zużycie ścierne metalowych elementów roboczych, Wydawnictwo Politechniki Śląskiej, Gliwice 1993.

[14] Hebda M., Wachal A.: Tribologia, Wydawnictwa Naukowo-Techniczne, Warszawa 1980.

KAMIL MUCHA, M.Sc., Eng. KRZYSZTOF KRAUZE, prof. Department of Mining, Dressing, Transport Machines

Faculty of Mechanical Engineering and Robotics AGH University of Science and Technology al. Mickiewicza 30, 30-059 Krakow, Poland

\{kmucha,krauze\}@agh.edu.pl 


\title{
Planowanie eksperymentu dla laboratoryjnych badań ścierności skał
}

\begin{abstract}
Właściwości fizykomechaniczne urabianej skały, takie jak wytrzymałość na ściskanie, wytrzymałość na rozciaganie, urabialność czy zwięzłość, bardzo często sa uwzględniane przy doborze sposobu urabiania, rodzaju maszyny urabiajacej, jak $i$ samych narzędzi urabiajacych. Jednakże bardzo rzadko uwzględnia się jedna z głównych przyczyn zużycia ściernego noży kombajnowych, jaka jest ścierność skat, gdyż brak jest jednoznacznej $i$ sprawdzonej metody jej określania.

$W$ artykule przedstawiono plan i metodykę badań, stanowisko do badania ścierności skat, przebieg przeprowadzenia badan wstępnych oraz statystyczne opracowanie wyników za pomoca programu Statistica i ustalenie ostatecznych wartości wielkości wejściowych $w$ badaniach zasadniczych. Metoda została opracowana $w$ aspekcie uwzględniania ścierności skat przy doborze i prognozowaniu zużycia narzędzi urabiających.
\end{abstract}

Słowa kluczowe: ścierność skał, plan doświadczenia, badania laboratoryjne, analiza statystyczna, narzędzia urabiające, zużycie ścierne

\section{WSTĘP}

Znajomość właściwości fizykomechanicznych skał odgrywa ważną rolę przy projektowaniu i wykonywaniu wszelkich przedsięwzięć inżynierskich w górnictwie i w budownictwie podziemnym. Jest ona niezbędna do oceny stateczności górotworu w sąsiedztwie wyrobisk oraz zapewnienia warunków bezpiecznego użytkowania wyrobisk i bezpiecznej pracy [1]. Parametry fizykomechaniczne należy również uznać za podstawę wyboru sposobu mechanicznego urabiania. Ich znajomość pozwala ocenić przydatność skał, a także umożliwia ocenę zachowania materiału skalnego podczas urabiania [2].

Nóż skrawający podczas eksploatacji jest elementem będącym bezpośrednio w kontakcie z urabianą calizną. Podczas urabiania dochodzi do jego zużycia, najczęściej przez ścieranie. Zużycie noży niesie za sobą bardzo poważne konsekwencje, wśród których można wymienić: zmiany geometrii i kształtu noża, ubytek ich masy, utratę zdolności skrawających, częste wymiany noży, skrócenie dyspozycyjnego czasu pracy maszyny urabiającej, zmniejszenie wydajności, wzrost energochłonności i kosztów wydobycia [3, 4].
Przy doborze narzędzi urabiających uwzględnia się różne aspekty, między innymi właściwości geologiczne, właściwości fizykomechaniczne skał, gdzie najczęściej branymi pod uwagę parametrami są wytrzymałość na jednoosiowe ściskanie oraz na jednoosiowe rozciąganie, zwięzłość czy urabialność. Należy również dobrać odpowiedni materiał i konstrukcję noży, tak aby przy danych parametrach i warunkach procesu skrawania ich trwałość była jak największa $[3,4]$.

Podczas doboru narzędzi urabiających bardzo rzadko bierze się pod uwagę ścierność skał. Jest to spowodowane brakiem jednoznacznie określonej metody jej wyznaczania. Jedyną powszechnie znaną metodą badania ścierności skał jest wyznaczenie wskaźnika CAI w teście ścierności Cerchar $[5,6]$. Metoda ta wykorzystywana jest przez firmę Sandvik, jednakże wyniki badań są tajemnicą firmy. Często metody określania ścierności skał są mylone z metodami badania ścieralności skał, co zostało opisane w publikacji [3].

W związku z powyższym opracowano nową metodę badania ścierności skał, którą opisano w niniejszym artykule. 


\section{STANOWISKO LABORATORYJNE}

Ścierność skał jest określania za pomocą wskaźnika ścierności $W_{z}$. Sposób jego wyznaczania oparto na metodzie oceny szybkości zużycia noży skrawających. W warunkach przemysłowych ich trwałość określa się zazwyczaj jako stosunek liczby zużytych noży do masy lub objętości urobionego minerału. Najczęściej jest to liczba noży zużytych na pozyskanie $1000 \mathrm{Mg}$ lub $1000 \mathrm{~m}^{3}$ urobku. Natomiast w warunkach laboratoryjnych szybkość zużycia noża czy noży (trwałość) najefektywniej można wyznaczyć przez ubytek masy w stosunku do urobionej przez nóż czy noże objętości próbki skalnej [4]. Na tej podstawie wskaźnik ścierności zdefiniowano jako stosunek ubytku masy wzorcowego stalowego próbnika do ubytku masy badanej próbki skalnej (1).

$$
W_{z}=\frac{M_{p a}}{M_{p i}}
$$

gdzie:

$$
\begin{gathered}
W_{z}-\text { wskaźnik ścierności [-], } \\
M_{p i}-\text { ubytek masy próbki }[\mathrm{g}] \\
M_{p a}-\text { ubytek masy próbnika }[\mathrm{g}],
\end{gathered}
$$
gdzie:

$$
M_{p a}=M_{p a b}-M_{p a a}
$$

gdzie:

$M_{p a b}$ - masa próbnika przed badaniem [g],

$M_{p a a}$ - masa próbnika po badaniu [g],

$$
M_{p i}=M_{p i b}-M_{p i a}
$$

gdzie:

$M_{p i b}$ - masa próbki przed badaniem [g],

$M_{\text {pia }}$ - masa próbki po badaniu [g].

Sposób wyznaczania wskaźnika ścierności wymusił zaprojektowanie i wykonanie stanowiska laboratoryjnego (rys. 1). Na stanowisku badawczym znajduje się zespół napędowy realizujący ruch obrotowy próbnika ze stałą prędkością obrotową. Na wale motoreduktora zabudowany jest uchwyt, w którym zamocowany jest nieruchomo stalowy próbnik. Wraz z próbką skalną tworzą parę ścierną (rys. 2). Przedmiotowy próbnik jest stale dociskany do czoła próbki skalnej za pomocą grawitacyjnego układu docisku z obciążnikami. Dokładny opis stanowiska został przedstawiony w publikacji [7].

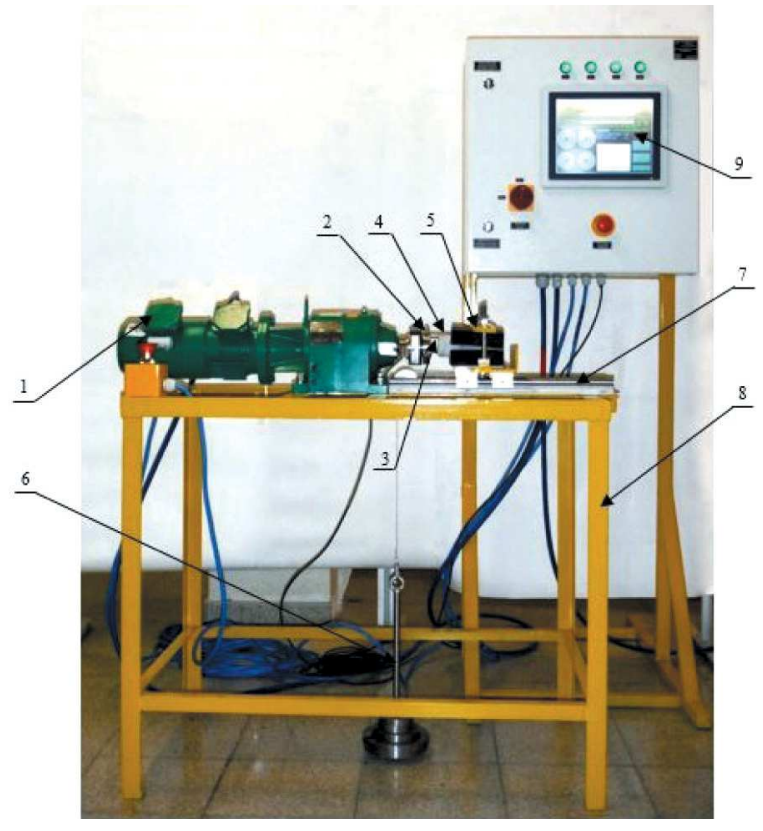

Rys. 1. Stanowisko do badania ścierności skat: 1 - zespót napędowy, 2 - próbnik, 3 - mocowanie próbnika, 4 - próbka skalna, 5 - uchwyt próbki skalnej, 6 - układ docisku, 7 - układ przesuwu, 8 - konstrukcja nośna, 9 - panel sterujący

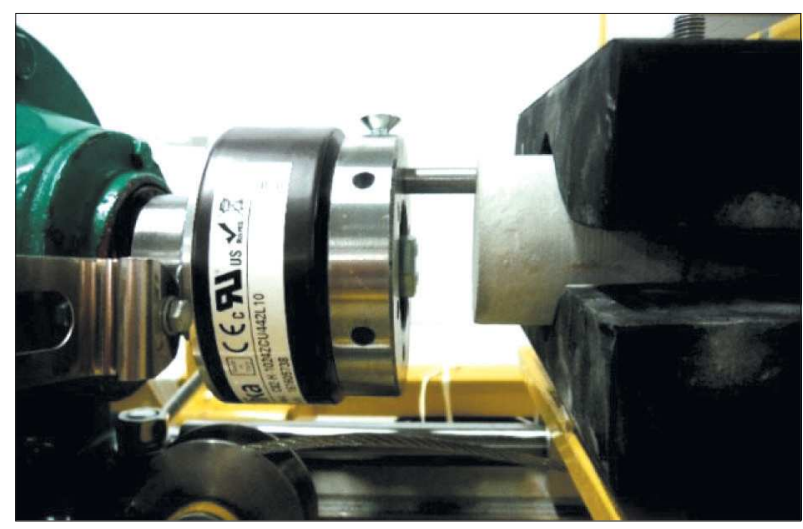

Rys. 2. Widok pary ściernej

\section{CEL I CHARAKTERYSTYKA OBIEKTU BADAŃ}

Pierwszym ważnym etapem badań jest postawienie problemu badawczego wymagającego rozwiązania na drodze doświadczalnej oraz charakterystyka obiektu badań. Celem każdego rodzaju badań doświadczalnych jest uzyskanie informacji dotyczącej zależności między wielkościami wejściowymi (parametry zadawane) a wielkościami wyjściowymi (wielkości poszukiwane). Tego rodzaju zależność najczęściej przedstawia się w postaci aproksymującej funkcji obiektu badań $[8,9]$. 
Charakterystyka obiektu badań polega na ustaleniu zbioru wielkości wejściowych i wyjściowych. Ten etap badań ma kluczowe znaczenie, gdyż błędy związane z niedokładnym rozpoznaniem obiektu badań mogą skutkować uzyskaniem nieadekwatnego modelu, a przede wszystkim stratą pieniędzy i czasu. Ważne jest zatem odpowiednie rozeznanie tematu, które zostało opisane w opracowaniu [3].

Głównym celem badań wstępnych opisywanych w niniejszym artykule było wyznaczenie postaci funkcji dla trzech różnych próbek skalnych, a następnie wyliczenie wartości wielkości wejściowych, które będą niezmienne w badaniach zasadniczych. Wartością wyjściową jest wskaźnik ścierności $W_{z}$, natomiast wielkościami wejściowymi są:

- siła docisku próbnika do próbki skalnej $P_{d}[\mathrm{~N}]$,

- prędkość obrotowa próbnika $n$ [obr/min],

- czas pojedynczej próby $t$ [min].

Przedmiotem badań były dwa rodzaje skał naturalnych (piaskowiec i porfir) oraz beton, które przedstawiono na rysunku 3.

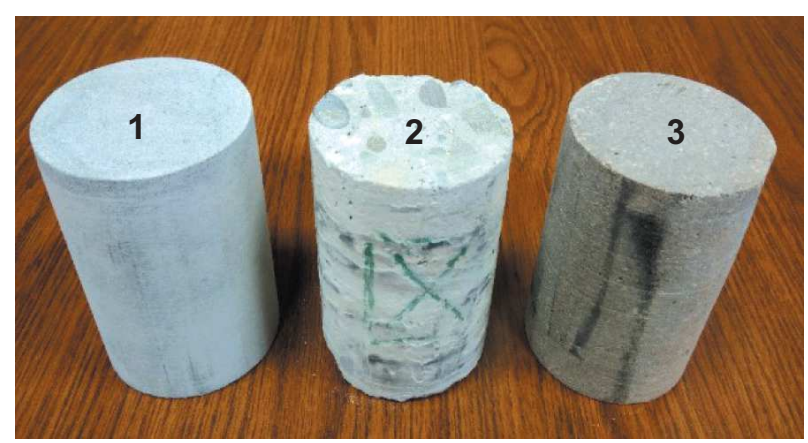

Rys. 3. Widok próbek przygotowanych do badań: 1 - piaskowiec, 2 - beton, 3 - porfir

Dobór takiego zestawu próbek był uwarunkowany różnymi właściwościami fizykomechanicznymi i zróżnicowanym składem mineralogicznym i chemicznym. Szczególnie zwrócono uwagę na wartość wytrzymałości na jednoosiowe ściskanie. Piaskowiec należy do skał o dużej wytrzymałości i ze względu na dużą zawartość $\mathrm{SiO}_{2}$ ma dobre właściwości ścierne. Porfir należy do skał o średniej wytrzymałości i również ma dobre właściwości ścierne ze względu na zawartość $\mathrm{SiO}_{2}$. Natomiast na próbki sztuczne dobrano beton $\mathrm{C} 16 / 20$, aby otrzymać próbki o małej wytrzymałości na ściskanie i dodatkowo dodano kruszywo bazaltowe, w celu sprawdzenia czy wtrącenia będą się wykruszać.
Tabela 1

\section{Wytrzymałość na ściskanie oraz procentowa zawartość $\mathrm{SiO}_{2}$ w badanych próbkach}

\begin{tabular}{|l|c|c|}
\hline Próbka & $\begin{array}{c}\text { Wytrzymalość na } \\
\text { jednoosiowe ściskanie } \\
\boldsymbol{R}_{\boldsymbol{c}}[\mathrm{MPa}]\end{array}$ & $\begin{array}{c}\text { Zawartość } \mathbf{S i O}_{\mathbf{2}} \\
{[\%]}\end{array}$ \\
\hline Piaskowiec & $100-110$ & 27,7 \\
\hline Porfir & $32-53$ & 21,9 \\
\hline Beton & $20-25$ & 15,2 \\
\hline
\end{tabular}

\section{WYBÓR PLANU DOŚWIADCZENIA}

Chcąc ograniczyć nakład pracy i czasochłonność, najczęściej zawęża się zakres badań, eliminując wielkości wejściowe lub zmniejszając liczbę wartości wielkości wejściowych [8]. Najlepszym rozwiązaniem jest zastosowanie odpowiedniego planu doświadczenia. Jedną z największych jego zalet jest możliwość uzyskania wymiernych efektów w postaci zmniejszenia nakładów pracy, potrzebnych na przeprowadzenie danego doświadczenia, jak również zmniejszenie nakładów czasu. Jednakże wybór planu doświadczenia zależy od celu i specyfiki danego rodzaju badań. Korzystając z teorii eksperymentu, należy wybrać plan doświadczenia, który będzie spełniał podstawowe kryteria informatywności, realizowalności oraz efektywności [8-10].

Jak wspomniano wcześniej, w przypadku opisywanych badań są trzy wielkości wejściowe i jedna wielkość wyjściowa. Przyjmując nieliniowe zależności funkcyjne pomiędzy wielkościami wejściowymi a wyjściowymi, przyjęto przeprowadzenie badania dla pięciu wartości pośrednich. Założono, że dla pierwszej zmiennej, jaką jest siła docisku $P_{d}$, zakres zmienności wynosił 150-350 N. Dla drugiej zmiennej, czyli prędkości obrotowej próbnika $n$ zakres zmienności to 20-55 obr/min, dla trzeciej zmiennej - czasu pojedynczej próby $t$ zakres wynosił 4-12 min.

Ze względu na szczególną efektywność i możliwość opisywania nieliniowych modeli obiektu badań, a przy tym kompozycyjność, czyli możliwość weryfikacji modelu liniowego, przyjęto plan Hartleya o oznaczeniu PS/DS-P:Ha $\mathrm{Ha}_{3}$ przy obszarze zmienności na hiperkuli (hK). Należy on do planów statycznych, zdeterminowanych, poliselekcyjnych dla trzech wielkości wejściowych, w którym stosuje się pięć różnych wartości dla każdej wielkości wejściowej [9]. 
Podstawową zasadą tworzenia planów poliselekcyjnych jest celowy dobór kombinacji wartości wielkości wejściowych (w założonym uprzednio zakresie) w taki sposób, aby istniała możliwość uzyskania wymaganej informacji naukowej przy ograniczonych nakładach pracy, czyli stosunkowo małej liczbie pomiarów $[9,10]$. Pomocny na tym etapie badań był program Statistica. Umożliwia on generowanie różnego rodzaju planów badań, dzięki modułowi „planowanie doświadczeń" [11].

Wybór planu poliselekcyjnego znacznie zmniejsza liczbę koniecznych prób w stosunku do planu kompletnego. Jak można zauważyć w tabeli 2, układy planu od numeru 11 do numeru 14 przedstawiają te same kombinacje wartości wielkości wejściowych. Powtórzenie doświadczenia dla tych kombinacji jest niezbędne w celu określenia błędów aproksymacji założonej funkcji obiektu badań.

Tabela 2

Układy planu Hartleya obrazujące kombinację wartości wielkości wejściowych podczas badań wstępnych

\begin{tabular}{|c|c|c|c|}
\hline $\begin{array}{c}\text { Uklady } \\
\text { planu } \\
\text { Hartleya }\end{array}$ & $\begin{array}{c}\text { Sila docisku } \\
\boldsymbol{P}_{\boldsymbol{d}}\end{array}$ & $\begin{array}{c}\text { Obroty } \\
\boldsymbol{n}\end{array}$ & $\begin{array}{c}\text { Czas } \\
\boldsymbol{t}\end{array}$ \\
\hline 1 & 192 & 27 & 10 \\
\hline 2 & 308 & 27 & 6 \\
\hline 3 & 192 & 48 & 6 \\
\hline 4 & 308 & 48 & 10 \\
\hline 5 & 150 & 37 & 8 \\
\hline 6 & 350 & 37 & 8 \\
\hline 7 & 250 & 20 & 8 \\
\hline 8 & 250 & 55 & 8 \\
\hline 9 & 250 & 37 & 4 \\
\hline 10 & 250 & 37 & 12 \\
\hline 11 & 250 & 37 & 8 \\
\hline 12 & 250 & 37 & 8 \\
\hline 13 & 250 & 37 & 8 \\
\hline 14 & 250 & 37 & 8 \\
\hline
\end{tabular}

Niestety po wykonaniu badań dla wyznaczonego planu eksperymentu i przeprowadzeniu analizy statystycznej wyników badań stwierdzono, że wyznaczone funkcje obiektu badań, dla każdej badanej próbki, są nieadekwatne w stosunku do wyników pomiarów.
Przeprowadzono dodatkowe badania dla kilku innych planów eksperymentów, jednakże za każdym razem uzyskiwano zbyt małą liczbę pomiarów, a tym samym niedokładną funkcję opisującą obiekt badań. W związku z powyższym wyniknęła potrzeba zastosowania jednak planu kompletnego.

\section{REALIZACJA BADAŃ}

Wybór planu kompletnego wiązał się z dużym nakładem pracy oraz był bardzo czasochłonny. Z uwagi na poznawczy charakter badań dla planu kompletnego rozszerzono zakres zmienności wielkości wejściowych w stosunku do wcześniej wspomnianych planów eksperymentu. Zdecydowano się na to, aby uzyskać większą ilość danych w celu wyznaczenia dokładniejszej funkcji aproksymującej obiektu badań. Zakresy zmienności oraz badane wartości dla planu kompletnego zestawiono w tabeli 3. Zadawane wartości wielkości wejściowych zostały wybrane symetrycznie dla każdego zakresu zmienności. Taki dobór jest konieczny w celu najdokładniejszego odzwierciedlenia charakteru zmienności wielkości wejściowych na wynik badania $[9,12]$.

Tabela 3

\section{Zakresy zmienności oraz wybrane wartości wielkości wejściowych}

\begin{tabular}{|l|c|c|c|}
\hline \multicolumn{1}{|c|}{$\begin{array}{c}\text { Wielkości } \\
\text { wejściowe }\end{array}$} & $\begin{array}{c}\text { Sila docisku } \\
\boldsymbol{P}_{\boldsymbol{d}}[\mathbf{N}]\end{array}$ & $\begin{array}{c}\text { Obroty } \boldsymbol{n} \\
{[\mathbf{o b r} / \mathbf{m i n}]}\end{array}$ & $\begin{array}{c}\text { Czas } \boldsymbol{t} \\
{[\mathbf{m i n}]}\end{array}$ \\
\hline $\begin{array}{l}\text { Zakres } \\
\text { zmienności }\end{array}$ & $100-400$ & $10-65$ & $2-15$ \\
\hline Badane & 100,200, & 10,30, & 2,5, \\
wartości & 300,400 & 50,65 & 10,15 \\
\hline
\end{tabular}

Kombinacje wartości wielkości wejściowych przyjęte do poszczególnych prób były określone przez przyjęty kompletny plan doświadczenia. Przy trzech wielkościach wejściowych i czterech wartościach badanych dla każdej z nich łącznie wykonano 64 próby $(4 \times 4 \times 4)$. Dla trzech skał łącznie liczba pojedynczych prób wyniosła 192. Ze względu na obszerną ilość danych poszczególnych układów planu kompletnego nie umieszczono w niniejszym artykule.

Badania wykonano na stanowisku laboratoryjnym do określania ścierności skał, które zostało opisane 
w rozdziale drugim, zgodnie $\mathrm{z}$ następującym planem badań:

- przygotowanie próbek skalnych oraz pomiar ich mas,

- przygotowanie próbników do badań oraz pomiar ich mas,

- zamocowanie próbnika i próbki skalnej w uchwytach na stanowisku,

- ustawienie czasu badania oraz prędkości obrotowej próbnika na panelu sterującym,

- zadanie siły docisku próbki skalnej do próbnika za pomocą grawitacyjnego układu docisku z obciążnikami,

- wykonanie badania,

- zwolnienie siły docisku,

- demontaż próbnika i pomiar jego masy,

- demontaż próbki skalnej i pomiar jej masy,

- obliczenie ubytku masy próbnika i próbki skalnej,

- wyznaczenie wskaźnika ścierności $W_{z}$.

Przeprowadzone badania oprócz wartości wskaźnika ścierności $W_{z}$ dla każdej kombinacji wartości wejściowych, umożliwily uzyskać wiele innych cennych następujących wniosków:

- czas próby 2 min jest zbyt krótki, zaś siła docisku próbnika do próbki skalnej $100 \mathrm{~N}$ oraz prędkość obrotowa próbnika $10 \mathrm{obr} / \mathrm{min}$ są zbyt małe, aby uzyskać mierzalne zużycie próbnika z dokładnością do 0,01 grama;

- prędkość obrotowa próbnika $65 \mathrm{obr} / \mathrm{min}$ oraz siła docisku $400 \mathrm{~N}$, niezależnie od czasu próby powodują jego nagrzewanie się i w konsekwencji prowadzi to do zużycia cieplnego próbnika, a nawet jego odkształcenia plastycznego.

Na podstawie powyższych obserwacji układy z tymi wartościami wejściowymi, a tym samym wartości wskaźnika ścierności $W_{z}$ nie były brane pod uwage przy przeprowadzaniu analizy wyników.

\section{ANALIZA WYNIKÓW I WYBÓR FUNKCJI OBIEKTU BADAŃ}

Po wyznaczeniu wskaźników ścierności dla wszystkich wyznaczonych układów planu kompletnego, przeprowadzono analizę wyników badań w celu wyznaczenia funkcji obiektu badań dla każdej próbki.

We wszystkich analizach statystycznych przyjęto poziom istotności $p=0,05$. Jest to wartość zwykle przyjmowana w technicznych badaniach doświadczalnych [8-12].

Pierwszym krokiem analizy wyników było sprawdzenie jednorodności wariancji. Jest to warunek konieczny do spełnienia. Brak jednorodności wariancji uniemożliwia poszukiwanie funkcji obiektu badań. Jednorodność wariancji przeprowadzono testem Browna-Forsythe'a z wykorzystaniem programu Statistica za pomocą modułu Statystyki podstawowe i tabele (Przekroje, prosta ANOVA). Jeżeli test daje wyniki statystycznie nieistotne $(p=0,05)$, to należy przyjąć hipotezę o jednorodności wariancji [8]. Jak można zauważyć na rysunku 4, dla wszystkich trzech badanych próbek skalnych poziom istotności $p$ jest większy od 0,05 , stąd jednorodność wariancji jest zachowana.

Przed wyznaczeniem funkcji obiektu badań sprawdzono również, czy wpływ wielkości wejściowej na wielkość wyjściową jest istotny. Weryfikację przeprowadzono za pomocą testu F Snedecora (Fishera). Wykorzystano moduł Statystyki podstawowe i tabele (Przekroje, prosta ANOVA, Analiza wariancji). Uzyskane wartości poziomu istotności $p$ mniejsze od 0,05 świadczą o istotnym wpływie wielkości wejściowych na wyjściowe.

Przeprowadzona analiza wariancji (rys. 5) z zastosowaniem testu F wykazała istotny wpływ siły docisku, prędkości obrotowej i czasu pojedynczej próby na wartość wskaźnika ścierności dla wszystkich trzech badanych próbek.

Podczas analizy wyników wartość zmiennej $P_{d}$ podzielono przez $10 \mathrm{w}$ celu minimalizacji błędów numerycznych. Następnie określono postać funkcji opisującej zależność empiryczną (4) dla każdej z badanych skał.

\begin{tabular}{|c|c|c|c|c|c|c|c|c|}
\hline \multirow[b]{2}{*}{ Zmienna } & \multicolumn{8}{|c|}{$\begin{array}{l}\text { Test jednorod. wariancji Browna-Forsythe'a (Plan kompletny) } \\
\text { Zaznaczone efekty są istotne z } \mathrm{p}<.05000\end{array}$} \\
\hline & $\begin{array}{c}\text { SS } \\
\text { Efekt }\end{array}$ & $\begin{array}{c}\mathrm{df} \\
\text { Efekt }\end{array}$ & $\begin{array}{c}\text { MS } \\
\text { Efekt }\end{array}$ & $\begin{array}{c}\text { SS } \\
\text { Błąd }\end{array}$ & $\begin{array}{c}\mathrm{df} \\
\text { Błąd }\end{array}$ & $\begin{array}{l}\text { MS } \\
\text { Bląd }\end{array}$ & $F$ & $p$ \\
\hline Wz (pias) & $1,1,120500$ & $\overline{3}$ & 0,56025 & $3,3,580000$ & $\overline{260}$ & 0,210588 & $2,2,660405$ & 0,098806 \\
\hline Wz (bet) & 0,114500 & 3 & 0,05725 & 1,097500 & 60 & 0,064559 & 0,886788 & 0,430196 \\
\hline Wz (por) & 0,009656 & 3 & 0,004828 & 0,033594 & 60 & 0,001976 & 2,443256 & 0,116766 \\
\hline
\end{tabular}




\begin{tabular}{|c|c|c|c|c|c|c|c|c|}
\hline \multirow[b]{2}{*}{ Zmienna } & \multicolumn{8}{|c|}{$\begin{array}{l}\text { Analiza wariancji (Plan kompletny) } \\
\text { Zaznaczone efekty są istotne } z \mathrm{p}<.05000\end{array}$} \\
\hline & $\begin{array}{c}\text { SS } \\
\text { Efekt }\end{array}$ & $\begin{array}{c}\text { df } \\
\text { Efekt }\end{array}$ & $\begin{array}{c}\text { MS } \\
\text { Efekt }\end{array}$ & $\begin{array}{c}\text { SS } \\
\text { Błąd }\end{array}$ & $\begin{array}{c}\text { df } \\
\text { Błąd }\end{array}$ & $\begin{array}{c}\text { MS } \\
\text { Btąd }\end{array}$ & $F$ & $p$ \\
\hline Wz (pias) & 29,06889 & 3 & 9,689629 & 77,74373 & 60 & 1,295729 & 7,478131 & 0,000247 \\
\hline Wz (bet) & 7,96197 & 3 & 2,653991 & 30,38804 & 60 & 0,506467 & 5,240201 & 0,002804 \\
\hline Wz (por) & 8,84422 & 3 & 2,948073 & 28,13938 & 60 & 0,468990 & 6,286009 & 0,000882 \\
\hline
\end{tabular}

Rys. 5. Wyniki analizy wariancji testem $F$ dla trzech badanych skat

Wstępne porównanie stopnia adekwatności różnych postaci funkcji aproksymujących opisujących zależność (4), zaowocowały wyborem funkcji w postaci wielomianu drugiego stopnia z podwójnymi interakcjami (5).

$$
\begin{aligned}
W_{z} & =f\left(P_{d}, n, t\right) \\
z & =b_{0}+b_{1} x_{1}+b_{2} x_{2}+b_{3} x_{3}+b_{11} x_{1}^{2}+b_{22} x_{2}^{2}+ \\
& +b_{33} x_{3}^{2}+b_{12} x_{1} x_{2}+b_{13} x_{1} x_{3}+b_{23} x_{2} x_{3}
\end{aligned}
$$

Liczba niewiadomych $b_{i}$ zaproponowanego wielomianu aproksymującego wynosi 10 i jest mniejsza od liczby układów planu, co powoduje spełnienie warunku koniecznego ze względu na kryterium informacyjności planu [7]. Stałe $b_{i}$ obliczono metodą estymacji quasi-Newtona przy użyciu programu Statistica.

Na podstawie analizy istotności współczynników $b_{i}$, przeprowadzonej przy wykorzystaniu testu $t$-Studenta, dokonano odrzucenia współczynników uznanych za nieistotne, przy poziomie istotności 0,05 . Wykorzystano moduł Zaawansowane modele liniowe i nieliniowe (Estymacja nieliniowa, Regresja użytkowania). Współczynniki istotne program zaznacza kolorem czerwonym (rys. 6). Następnie z wielomianu usunięto składowe ze współczynnikami nieistotnymi i ponownie wygenerowano współczynniki równania, tak aby wszystkie były zaznaczone kolorem czerwonym (czyli wszystkie uznane za istotne).
Na rysunku 6 przedstawiono przykład wyników dla piaskowca. W ten sam sposób analizę istotności przeprowadzono również dla porfiru i betonu. Funkcje aproksymujące dla trzech badanych skał są następujące:

- piaskowiec:

$$
\begin{aligned}
W_{z_{1}} & =-3,67+0,66 \cdot t+ \\
& +0,2 \cdot P_{d}-0,03 \cdot t^{2}-3 \cdot 10^{-3} \cdot P_{d}^{2}
\end{aligned}
$$

- beton:

$$
\begin{aligned}
W_{z_{2}} & =-2,45+0,3 \cdot t+ \\
& +0,17 \cdot P_{d}-0,014 \cdot t^{2}-3,3 \cdot 10^{-3} \cdot P_{d}^{2}
\end{aligned}
$$

- porfir:

$$
\begin{aligned}
W_{z_{3}} & =-6,8 \cdot 10^{-3} \cdot t^{2}-2,6 \cdot 10^{-4} \cdot n^{2}- \\
& +7,2 \cdot 10^{-4} \cdot P_{d}^{2}+1,6 \cdot 10^{-3} \cdot t \cdot n+ \\
& +4,3 \cdot 10^{-3} \cdot t \cdot P_{d}+8,7 \cdot 10^{-4} \cdot n \cdot P_{d}
\end{aligned}
$$

\begin{tabular}{|c|c|c|c|c|c|c|c|c|c|c|c|c|c|}
\hline & \multicolumn{9}{|c|}{ 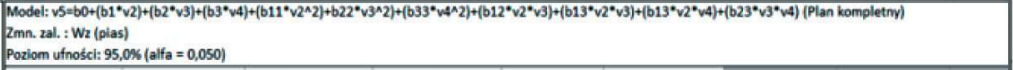 } & & & & \\
\hline & Ocena & $\begin{array}{l}\text { Bład } \\
\text { stand. }\end{array}$ & $\begin{array}{l}\text { Wart. t } \\
\mathrm{df}=54\end{array}$ & p & $\begin{array}{l}\text { Dol. uf } \\
\text { Granica }\end{array}$ & $\begin{array}{l}\text { Górn. uf } \\
\text { Granica }\end{array}$ & & & & & & & \\
\hline bo & $-3,77469$ & 1,1183 & $-3,37538$ & 0,001372 & $-6,01675$ & $-1,53263$ & & & & & & & \\
\hline b1 & 0,55707 & 0,132698 & 4,19807 & 0,000101 & 0,29103 & 0,82312 & & & & & & & \\
\hline b2 & 0,03936 & 0,031201 & 1,26143 & 0,212577 & $-0,02320$ & 0,10191 & & & & & & & \\
\hline b3 & 0,16433 & 0,064326 & 2,55465 & 0,013482 & 0,03536 & 0,29329 & & & & & & & \\
\hline b11 & $-0,02925$ & 0,006507 & $-4,49572$ & 0,000037 & $-0,04230$ & $-0,01621$ & & \multirow{2}{*}{\multicolumn{6}{|c|}{ 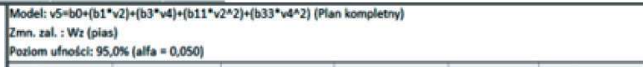 }} \\
\hline b22 & $-0,00052$ & 0,000355 & $-1,46293$ & 0,149282 & $-0,00123$ & 0,00019 & & & & & & & \\
\hline b33 & $-0,00310$ & 0,001132 & $-2,67230$ & 0,009939 & $-0,00543$ & $-0,00780$ & & \multirow[t]{2}{*}{ Ocena } & \multirow{2}{*}{$\begin{array}{l}\text { Bład } \\
\text { stand. }\end{array}$} & \multirow{2}{*}{$\begin{array}{l}\text { Wart. t } \\
\mathrm{df}=54\end{array}$} & \multirow[t]{2}{*}{ p } & \multirow{2}{*}{$\begin{array}{l}\text { Dol. uf } \\
\text { Granica }\end{array}$} & \multirow{2}{*}{$\begin{array}{l}\text { Górn. uf } \\
\text { Granica }\end{array}$} \\
\hline b12 & $-0,00113$ & 0,001132 & $-1,00215$ & 0,320743 & $-0,00340$ & 0,00113 & & & & & & & \\
\hline b13 & 0,00206 & 0,002098 & 0,98403 & 0,329489 & $-0,00214$ & 0,00627 & bo & $-3,66638$ & 0,766369 & $-4,78409$ & 0,000012 & $-5,19988$ & $-2,13288$ \\
\hline \multirow[t]{3}{*}{ b23 } & 0,00071 & 0,005010 & 1,40964 & 0,164380 & $-0,00030$ & 0,00171 & b1 & 0,56475 & 0,117299 & 4,81459 & 0,000011 & 0,33003 & 0,79946 \\
\hline & & & & & & & b3 & 0,20822 & 0,060836 & 3,42258 & 0,001133 & 0,08648 & 0,32995 \\
\hline & & & & & & & b11 & $-0,02925$ & 0,006711 & $-4,35876$ & 0,000053 & $-0,04268$ & $-0,01582$ \\
\hline
\end{tabular}

gdzie:

$W_{z}$ - wskaźnik ścierności [-],

$t$ - czas próby [min],

$n$ - prędkość obrotowa próbnika [obr/min],

$P_{d}-$ siła docisku próbnika do próbki skalnej [N].

Rys. 6. Eliminacja wspótczynników nieistotnych w programie Statistica na przykładzie wyników badań piaskowca 
Po usunięciu współczynników nieistotnych w każdej wyznaczonej funkcji sprawdzono adekwatność funkcji obiektu badań dla wyników pomiarów. Weryfikację adekwatności przeprowadzono testem $\chi^{2}$ (chi-kwadrat). Uzyskany poziom istotności $p$ wyniósł 0,120 (średnio) i był on większy od 0,05 , co świadczy, że otrzymane funkcje są adekwatne w stosunku do wyników pomiarów. Dodatkowo sprawdzono również współczynniki korelacji $R$ dla wyznaczonych funkcji. Dla piaskowca wyniósł on $R=0,92$, dla porfiru $R=0,90$, a dla betonu $R=0,81$ (rys. 7).

\begin{tabular}{|l|c|c|c|}
\hline $\begin{array}{l}\text { Zależna } \\
\text { Zm. }\end{array}$ & $\begin{array}{c}\text { Wielokr. } \\
\text { R }\end{array}$ & $\begin{array}{c}\text { Wielokr. } \\
\text { R2 }\end{array}$ & $\begin{array}{c}\text { Skorygow } \\
\text { R2 }\end{array}$ \\
\hline Wz (pias) & 0,918444 & 0,843539 & 0,765309 \\
Wz (bet) & 0,907918 & 0,824316 & 0,736473 \\
Wz (por) & 0,808076 & 0,652987 & 0,479480 \\
\hline
\end{tabular}

Rys. 7. Wspótczynniki korelacji dla wyznaczonych funkcji

Następnie z funkcji (6), (7), (8) ułożono układ równań (9) i rozwiązano go za pomocą programu Matlab w celu otrzymania ostatecznych wartości wielkości wejściowych $P_{d}, n$ i $t$. Każde równanie przyrównano do maksymalnej wartości wskaźnika ścierności $W_{z}$, jaką otrzymano podczas badań, w celu wyznaczenia minimalnych wartości wielkości wejściowych, przy których można uzyskać największe zużycie próbnika.

$$
\left\{\begin{array}{l}
-3.67+0.66 \cdot t+0.2 \cdot P_{d}-0.03 \cdot t^{2}-3 \cdot 10^{-3} \cdot P_{d}^{2}=3.0 \\
-2.45+0.3 \cdot t+0.17 \cdot P_{d}-0.014 \cdot t^{2}-3.3 \cdot 10^{-3} \cdot P_{d}^{2}=1.4 \\
-6.8 \cdot 10^{-3} \cdot t^{2}-2.6 \cdot 10^{-4} \cdot n^{2}-7.2 \cdot 10^{-4} \cdot P_{d}^{2}+1.6 \cdot 10^{-3} \cdot t \cdot n+ \\
\quad+4.3 \cdot 10^{-3} \cdot t \cdot P_{d}+8.7 \cdot 10^{-4} \cdot n \cdot P_{d}=1.7
\end{array}\right.
$$

Po rozwiązaniu powyższego układu równań otrzymano następujące wartości wielkości wejściowych, tj. czas próby $t=7,88 \mathrm{~min}$, prędkość obrotowa próbnika $n=50,37 \mathrm{obr} / \mathrm{min}$ oraz siła docisku próbnika do próbki skalnej $P_{d}=30,48 \mathrm{~N}$.
Jak wcześniej wspomniano, wartości siły $P_{d}$ podzielono przez $10 \mathrm{w}$ celu zmniejszenia błędów numerycznych. Stąd kolejnym etapem było przeprowadzenie badań sprawdzających dla trzech badanych skał z następującymi wartościami wielkości wejściowych: $t=8 \mathrm{~min}, n=50 \mathrm{obr} / \mathrm{min}, P_{d}=300 \mathrm{~N}$.

Następnie wykonano badania sprawdzające dla wyznaczonych wielkości wejściowych dla trzech badanych skał. W przypadku każdej skały wykonano pięć powtórzeń w celu sprawdzenia powtarzalności wyników. Wyniki zestawiono w tabeli 4. Dodatkowo do każdego z wyznaczonych równań podstawiono wyliczone wartości wejściowe i otrzymano:

- dla piaskowca:

$$
\begin{aligned}
& W_{z_{1}}=-3,67+0,66 \cdot 8+0,2 \cdot 35- \\
& \quad+0,03 \cdot 8^{2}-3 \cdot 10^{-3} \cdot 35^{2}=3,0
\end{aligned}
$$

- dla betonu:

$$
\begin{aligned}
& W_{z_{2}}=-2,45+0,3 \cdot 8+0,17 \cdot 35- \\
& \quad+0,014 \cdot 8^{2}-3,3 \cdot 10^{-3} \cdot 35^{2}=1,0
\end{aligned}
$$

- dla porfiru:

$$
\begin{aligned}
W_{z_{3}} & =-6,8 \cdot 10^{-3} \cdot 8^{2}-2,6 \cdot 10^{-4} \cdot 50^{2}- \\
& +7,2 \cdot 10^{-4} \cdot 35^{2}+1,6 \cdot 10^{-3} \cdot 8 \cdot 50 \\
& +4,3 \cdot 10^{-3} \cdot 8 \cdot 35+8,7 \cdot 10^{-4} \cdot 50 \cdot 35=1,4
\end{aligned}
$$

Analizując wartości wskaźnika ścierności $W_{z} \mathrm{z}$ tabeli 4 , można zauważyć, że wyniki badań są prawie identyczne z tymi otrzymanymi z równań. Oznacza to, że funkcja aproksymująca została dobrze dobrana i dokładnie opisuje obiekt badań.

Jak wcześniej wspomniano, w przypadku kilku prób dochodziło do odkształcenia plastycznego stalowego próbnika. Zbyt duża temperatura próbnika może po-

\begin{tabular}{|c|c|c|c|c|c|c|}
\hline Lp. & $P_{d}[\mathrm{~N}]$ & $n[\mathrm{obr} / \mathrm{min}]$ & $t[\mathrm{~min}]$ & $\begin{array}{c}W_{z} \\
\text { (piaskowiec) }\end{array}$ & $\begin{array}{c}W_{z} \\
\text { (beton) }\end{array}$ & $\begin{array}{c}W_{z} \\
\text { (porfir) }\end{array}$ \\
\hline 1 & \multirow{5}{*}{350} & \multirow{5}{*}{50} & \multirow{5}{*}{8} & 3,2 & 1,0 & 1,4 \\
\hline 2 & & & & 3,0 & 1,1 & 1,3 \\
\hline 3 & & & & 3,0 & 1,1 & 1,3 \\
\hline 4 & & & & 3,1 & 1,0 & 1,3 \\
\hline 5 & & & & 2,9 & 1,1 & 1,4 \\
\hline \multicolumn{4}{|c|}{ Średnia wartość z badań } & 3,1 & 1,1 & 1,3 \\
\hline \multicolumn{4}{|c|}{ Wartość z równań } & 3,0 & 1,0 & 1,4 \\
\hline
\end{tabular}
wodować zmianę właściwości materiałowych stali oraz prowadzić do zużycia cieplnego próbnika. Ze względu na to dla wyznaczonych wartości wielkości wejściowych za pomoca kamery termowizyjnej sprawdzono temperaturę próbnika dla każdej próby z tabeli 4.

Tabela 4

Zestawienie wyników badań trzech skał dla wyznaczonych wielkości wejściowych 
Jak widać na rysunku 8, niezależnie od rodzaju próbki, maksymalna temperatura próbnika oscyluje w granicach $55-70^{\circ} \mathrm{C}$. Taka temperatura nie powoduje zbyt dużego nagrzewania się próbnika ani większego wpływu zużycia cieplnego nad zużyciem ściernym [13, 14].

a)

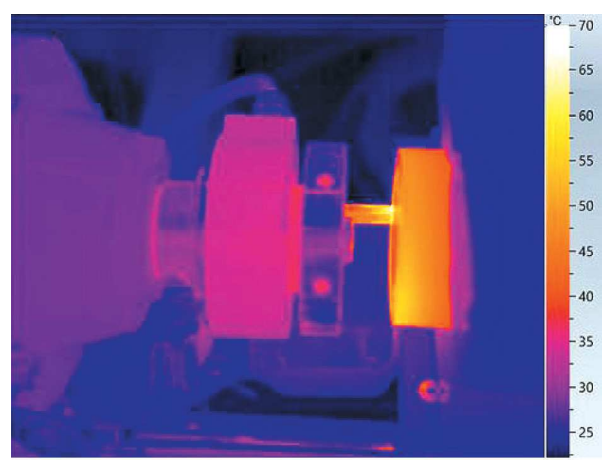

b)

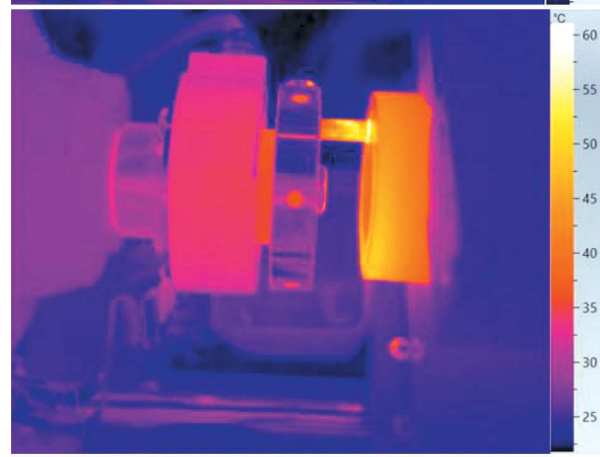

c)



Rys. 8. Obrazy termograficzne rozkładu maksymalnej temperatury podczas badań:

a) piaskowca; b) porfiru; c) betonu

\section{PODSUMOWANIE}

Przeprowadzenie badań wstępnych oraz statystyczne opracowanie wyników pozwoliło na zweryfikowanie założeń oraz wniesienie poprawek do planu i metodyki badań. Wybór planu kompletnego pozwolił zachować zadowalająca dokładność wyznaczenia funkcji aproksymującej wzajemne zależności pomiędzy wielkościami wejściowymi i wielkością wyjściową. Osiągnięto najważniejszy cel, jakim było ustalenie ostatecznych wartości wielkości wejściowych: siły docisku próbnika do czoła próbki skalnej równej 300 N, prędkości obrotowej próbnika równej 50 obr/min oraz czasu badania wynoszacego $8 \mathrm{~min}$.

Następnym krokiem będzie przeprowadzenie badań zasadniczych dla różnych typów skał. Będą to między innymi wapień, dolomit, granit, marmur, rudy metali, różne rodzaje piaskowców i bazalt.

\section{Podziękowania}

Prace finansowane $\mathrm{z}$ grantu dziekańskiego na Wydziale Inżynierii Mechanicznej i Robotyki AGH w ramach umowy numer 15.11.130.841.

\section{Literatura}

[1] Piątek P.: Test punktowy, test brazylijski i test na jednoosiowe ściskanie - badania porównawcze, „Górnictwo i Geoinżynieria" 2008, 32, 1: 285-292.

[2] Hobler M.: Badania fizykomechanicznych własności skat, Państwowe Wydawnictwo Naukowe, Warszawa 1977.

[3] Krauze K., Mucha K.: Analiza metod określania ścierności skat, w: Mechanizacja, automatyzacja i robotyzacja $w$ górnictwie. Tom 1: Wybrane problemy górnictwa podziemnego. Monografia, red. K. Krauze, Lędziny - Kraków 2015: 171-180.

[4] Krauze K., Bołoz Ł., Wydro T., Mucha K.: Durability testing of tangential - rotary picks made of different materials, „Mining - Informatics, Automation and Electrical Engineering” 2017, 1: 26-34.

[5] Käsling H., Thuro K.: Determining abrasivity of rock and soil in the laboratory, w: Geologically Active. Proceedings of the 11th IAEG Congress, Auckland, New Zealand, 2010: 1973-1980.

[6] Nilsen B., Dahl F., Holzhauser J., Raleigh P.: Abrasivity testing for rock and soil, ,Tunnels and Tunnelling International" 2006, 4: 47-49.

[7] Krauze K., Mucha K.: Laboratoryjna metoda badania ścierności skat, w: Mechanizacja, automatyzacja i robotyzacja w górnictwie. Tom 1: Wybrane problemy górnictwa podziemnego. Monografia, red. K. Krauze, Lędziny - Kraków 2016: 118-125.

[8] Konkol J.: Wprowadzenie do praktycznego planowania eksperymentu, Wydawnictwo StatSoft Polska Sp. z o.o., Kraków 2008: 43-58.

[9] Polański Z.: Planowanie doświadczeń w technice, Państwowe Wydawnictwo Naukowe, Warszawa 1984.

[10] Górecka R.: Teoria i technika eksperymentu, Wydawnictwo Politechniki Krakowskiej, Kraków 1996.

[11] Rabiej M.: Statystyka z programem Statistica, Wydawnictwo Helion, Gliwice 2012.

[12] Strzałkowski A., Śliżyński A.: Matematyczne metody opracowania wyników pomiarów, Państwowe Wydawnictwo Naukowe, Warszawa 1973.

[13] Gierek A.: Zużycie ścierne metalowych elementów roboczych, Wydawnictwo Politechniki Śląskiej, Gliwice 1993.

[14] Hebda M., Wachal A.: Tribologia, Wydawnictwa Naukowo-Techniczne, Warszawa 1980.

mgr inż. KAMIL MUCHA prof. dr hab. inż. KRZYSZTOF KRAUZE Katedra Maszyn Górniczych, Przeróbczych i Transportowych Wydziat Inżynierii Mechanicznej i Robotyki AGH Akademia Górniczo-Hutnicza im. Stanisława Staszica w Krakowie al. A. Mickiewicza 30, 30-059 Kraków \{kmucha,krauze\}@agh.edu.pl 